\title{
AN ANALYSIS OF EFL STUDENTS' PERCEPTION OF POWERPOINT USED AS ENGLISH LEARNING MEDIA IN CLASSROOM
}

\author{
Rekian Paramasti Ratu; Cahya Komara \\ University of Muhammadiyah Prof. Dr. HAMKA \\ raturekian@gmail.com, cahya.komara@uhamka.ac.id
}

\begin{abstract}
This study investigated students' perception of PowerPoint software used as learning media in the classroom. The aim of this study to get empirical data or evidence on whether the students' perception of Microsoft PowerPoint they used for studying English, especially EFL students in the classroom. Thus, in this research, the participants involved 900 EFL students in two different layers of the school; junior and senior high schools by applying close-ended and open-ended questionnaires to gather the data. The data was analyzed through quantitative (close-ended questionnaire) and qualitative (open-ended questionnaires) method. The result of the close-ended questionnaire showed that if learning English using Ms. PPT can increase students' activeness, work up students' motivation, and improve students' English competence. In the meantime, the open-ended questionnaire also provided the same findings that more students agreed or said yes (positive side) of learning using MS. PowerPoint. Therefore, it can be concluded that students' perceptions of Ms. PowerPoint were good and exciting. Also, the students felt learning English by using Ms. PowerPoint provided more help, especially in the context of raising activeness, motivation, and English competence in EFL classroom.
\end{abstract}

Keywords: Student's perception, powerpoint, students' activeness, students' motivation

\section{INTRODUCTION}

In the education world, learning media are known for their importance for the teachers to support the teaching and learning process in the classroom. In the beginning, learning media used in the classroom is only in simple forms, such as teachers use a blackboard with chalk or use a whiteboard with markers (Callanan, 2016; Gusnita, Sofiana, \& Antika, 2016) to deliver materials. However, learning media has evolved significantly with different types or models. For example, the new innovation of computer technology as learning media has created a better opportunity for both students and teachers to improve English competence, such as listening and speaking with the use of advanced video media in class (Rahmi, 2014). and the learning media is needed to create a pleasant classroom learning environment that can facilitate students to master English learning well (Hafis, 2013). Therefore, the use of learning media is now crucial to be applied, and teachers cannot neglect it for the sake of teaching and learning a matter of their students.

As previously mentioned, computer technology becomes the foremost learning media that may accommodate teachers for transferring knowledge for their students. One of the excellent 
software or programs that existed on the computer is well-known by PowerPoint. PowerPoint is a presentation program that can be made into a beautiful and creative slide show that can display text, images, audio, and video (Frandsen, 2011). PowerPoint in the classroom has a more significant positive impact and self-efficacy than traditional learning using the whiteboard. When the use of PowerPoint stops, students' interest in learning tends declines, even though teaching and learning are still ongoing. The result indicates that using learning media of PowerPoint in the classroom is better than the traditional one (Apperson, Laws, \& Scepansky, 2006).

Apart from the advantages described previously, there are some drawbacks of using PowerPoint in learning in EFL classes. First, the common problem found in PowerPoint is technicality matters. For instance, the delay in learning when the media is not running during the learning process is sometimes annoying. Next, students become lazy to record the material that has been learned because the teacher usually makes one slide with many explanations. Last, students may feel bored with the fullness of words in the slide. According to (Hafis, 2013), some students assume that they prefer traditional learning to advanced learning media because learning to use slides forces them to understand learning material faster. The results show that PowerPoint has also got a negative perception of students.

To encounter the bias whether PowerPoint is positive or negative learning media on the perspective of Indonesia EFL students, especially in Jakarta, From this situation, we formulate our research questions as follows: "What is the EFL students' perception of PowerPoint used as learning media in their classroom?". To get the empirical data or evidence of EFL students' perception of PowerPoint as English learning media in their class. This study may reveal either this media is positive or negative on the eyes of EFL junior and senior high school students limited in Jakarta area.

\section{METHOD}

In this research, the writer used both quantitative and qualitative methods or mixed-method with the application of survey design of close-ended and open-ended questionnaires to collect the data within focus on the EFL students' perceptions of Ms. PowerPoint as learning teaching in the classroom. According to Creswell (2011), mixed research is research that combines qualitative research with quantitative research together in a study to obtain data that are more comprehensive, valid, relevant, and objective. The writer used quantitative in order to calculate results of student perceptions in the Closed-ended questions that consisted of 10 items adopted and modified from (Abdellatif, 2015) instrument within Likert Scale 5 to 1 format of Strongly Agree (SA), Agree (A), Neutral (N), Disagree (D), and Strongly Disagree (SD). This questionnaire was compiled based on indicators of independent variables, namely about Ms. PowerPoint media which can reveal the quantitatively of students' perception of Ms. PowerPoint.

Meanwhile, qualitative was used to analyze and interpret the results of their answers with the used open-ended questions in which they can respond as they desired which were used to gain deep information of students' perception of Ms. PowerPoint. the researcher used were 900 
students as respondents. The researcher used online Google Form to collect the data. Google Forms is a survey administration app that is included in the Google Drive office suite along with Google Docs, Google Sheets, and Google Slides.

After the data was collected, the writer used a formula (Warsito, 1992) to examine the frequency and percentage of each item's responses to find out students' perceptions of PowerPoint in EFL classroom. After the data has been analyzed, the writer interpreted the ten items into a more specific description. Furthermore, the writer recapitulated the whole items to see the student perception of Ms. PowerPoint. Next, to analyze the open-ended questionnaire, the writer classified all the responses from the participant into specific perceptions regarding media PowerPoint in EFL classroom.

\section{FINDINGS AND DISCUSSION}

In this chapter, the writer presented the findings of data gathered from two instruments. The instruments were used to get empirical data of student perception the Ms. PowerPoint used as learning media in EFL classroom at Jakarta area. The first sub-section explained the result of closeended questions. Meanwhile, the second sub-section explained the result of open-ended questions. Below were the details:

\section{Close-Ended Questionnaire Result}

To collect the typical student's perception about Ms. PowerPoint, the writer used a close-ended questionnaire. The close-ended questionnaire consisted of 10 items number with five optional answers which did not have a correct or wrong answer; Strongly Agree (SA), Agree (A), Neutral (N), Disagree (D), and Strongly Disagree (SD). The 900 respondents have given and exposed their perception honestly in the questionnaire. The result was as follow:

Table 1: Participants' Answer for the Questionnaire

\begin{tabular}{|c|c|c|c|c|c|c|c|}
\hline No & Statements & $\mathbf{X}$ & SA & $\mathbf{A}$ & $\mathbf{N}$ & D & SD \\
\hline 1. & $\begin{array}{l}\text { I feel excited when my } \\
\text { teacher teaching the material } \\
\text { using PowerPoint }\end{array}$ & 3,83 & $\begin{array}{c}159 \\
(17.7 \%)\end{array}$ & $\begin{array}{c}455 \\
(50.6 \%)\end{array}$ & $\begin{array}{c}265 \\
(29.5 \%)\end{array}$ & $\begin{array}{c}19 \\
(2.1 \%)\end{array}$ & $\begin{array}{c}2 \\
(0.2 \%)\end{array}$ \\
\hline 2. & $\begin{array}{l}\text { I feel more interested in } \\
\text { learning when my teacher } \\
\text { uses PowerPoint in class }\end{array}$ & 3,83 & $\begin{array}{c}183 \\
(20,33 \%)\end{array}$ & $\begin{array}{c}414 \\
(46,00 \%)\end{array}$ & $\begin{array}{c}275 \\
(30,56 \%)\end{array}$ & $\begin{array}{c}26 \\
(2,89 \%)\end{array}$ & $\begin{array}{c}2 \\
(0,22 \%)\end{array}$ \\
\hline 3. & $\begin{array}{l}\text { I feel motivated in learning } \\
\text { when my teacher teaches } \\
\text { using PowerPoint }\end{array}$ & 3,75 & $\begin{array}{c}120 \\
(13,33 \%)\end{array}$ & $\begin{array}{c}461 \\
(51,22 \%)\end{array}$ & $\begin{array}{c}297 \\
(33,00 \%)\end{array}$ & $\begin{array}{c}21 \\
(2,33 \%)\end{array}$ & $\begin{array}{c}1 \\
(0,11 \%)\end{array}$ \\
\hline 4. & $\begin{array}{l}\text { I feel my interactions are very } \\
\text { strong when my teacher uses } \\
\text { PowerPoint in class }\end{array}$ & 3,51 & $\begin{array}{c}83 \\
(9,22 \%)\end{array}$ & $\begin{array}{c}364 \\
(40,44 \%)\end{array}$ & $\begin{array}{c}390 \\
(43,33 \%)\end{array}$ & $\begin{array}{c}59 \\
(6,56 \%)\end{array}$ & $\begin{array}{c}4 \\
(0,44 \%)\end{array}$ \\
\hline 5. & $\begin{array}{l}\text { I feel more understanding } \\
\text { when my teacher teaches } \\
\text { using PowerPoint }\end{array}$ & 3,58 & $\begin{array}{c}113 \\
(12,56 \%)\end{array}$ & $\begin{array}{c}369 \\
(41,00 \%)\end{array}$ & $\begin{array}{c}347 \\
(38,56 \%)\end{array}$ & $\begin{array}{c}67 \\
(7,44 \%)\end{array}$ & $\begin{array}{c}4 \\
(0,44 \%)\end{array}$ \\
\hline
\end{tabular}




\begin{tabular}{|c|c|c|c|c|c|c|c|}
\hline 6. & $\begin{array}{l}\text { I feel that using PowerPoint in } \\
\text { learning is better than using } \\
\text { textbooks }\end{array}$ & 3,41 & $\begin{array}{c}183 \\
(20,33 \%)\end{array}$ & $\begin{array}{c}414 \\
(46,00 \%)\end{array}$ & $\begin{array}{c}275 \\
(30,56 \%)\end{array}$ & $\begin{array}{c}26 \\
(9,22 \%)\end{array}$ & $\begin{array}{c}2 \\
(0,22 \%)\end{array}$ \\
\hline 7. & $\begin{array}{l}\text { PowerPoint makes students } \\
\text { ask the teacher more question } \\
\text { in class learning }\end{array}$ & 3,48 & $\begin{array}{c}88 \\
(9,78 \%)\end{array}$ & $\begin{array}{c}361 \\
(40,11 \%)\end{array}$ & $\begin{array}{c}354 \\
(39,33 \%)\end{array}$ & $\begin{array}{c}93 \\
(10,33 \%)\end{array}$ & $\begin{array}{c}4 \\
(0,44 \%)\end{array}$ \\
\hline 8. & $\begin{array}{l}\text { I feel learning to use } \\
\text { PowerPoint improves my } \\
\text { ability to learn }\end{array}$ & 3,56 & $\begin{array}{c}76 \\
(8,44 \%)\end{array}$ & $\begin{array}{c}409 \\
(45,44 \%)\end{array}$ & $\begin{array}{c}363 \\
(40,33 \%)\end{array}$ & $\begin{array}{c}50 \\
(5,56 \%)\end{array}$ & $\begin{array}{c}2 \\
(0,22 \%)\end{array}$ \\
\hline 9. & $\begin{array}{l}\text { PowerPoint makes students } \\
\text { curious about the material in } \\
\text { the class }\end{array}$ & 3,58 & $\begin{array}{c}108 \\
(12,00 \%)\end{array}$ & $\begin{array}{c}368 \\
(40,89 \%)\end{array}$ & $\begin{array}{c}368 \\
(40,89 \%)\end{array}$ & $\begin{array}{c}51 \\
(5,67 \%)\end{array}$ & $\begin{array}{c}5 \\
(0,56 \%)\end{array}$ \\
\hline 10. & $\begin{array}{l}\text { I feel my grades increase } \\
\text { more when my teacher } \\
\text { teaches using PowerPoint }\end{array}$ & 3,30 & $\begin{array}{c}53 \\
(5,89 \%)\end{array}$ & $\begin{array}{c}262 \\
(29,11 \%)\end{array}$ & $\begin{array}{c}495 \\
(55,00 \%)\end{array}$ & $\begin{array}{c}83 \\
(9,22 \%)\end{array}$ & $\begin{array}{c}7 \\
(0,78 \%)\end{array}$ \\
\hline
\end{tabular}

From 10 items that have been responded by 900 students, the writer can identify and categorize three primary perceptions of learning English using Ms. PowerPoint which was positive in terms of raising students' Activeness, Motivation, and English Competence. Here was the categorization or classification of the perception results of the data shown in the table below:

Table 2: Recapitulation of Students' Perception

\begin{tabular}{ccccc}
\hline & & \multicolumn{3}{c}{ Percentage (\%) } \\
\cline { 3 - 5 } Classification & Number & SA + A & N & D + SD \\
\hline $\begin{array}{c}\text { Learning English using PPT can increase } \\
\text { Students' Activeness }\end{array}$ & $4,7,9$ & $50,81 \%$ & $41,19 \%$ & $8,00 \%$ \\
\hline $\begin{array}{c}\text { Learning English using PPT can improve } \\
\text { Students' Motivation }\end{array}$ & $1,2,3$ & $66,37 \%$ & $33,44 \%$ & $2,63 \%$ \\
\hline $\begin{array}{c}\text { Learning English using PPT can affect } \\
\text { Students' English Competence }\end{array}$ & $5,6,8,10$ & $52,19 \%$ & $41,11 \%$ & $6,69 \%$ \\
\hline Total & $\mathbf{1 0 ~ I t e m s ~}$ & & & \\
\hline
\end{tabular}

Concerning to the recapitulation of table 4.2 above, it can be seen that the dominant respond shown by students' perception was strongly agree and agree in the context of learning English using Ms. PowerPoint can increase their activeness level (50,81\%), their motivation (66,37\%), and English competence (52,19\%). The majority of students or respondents viewed and selected learning English using Ms. PowerPoint was positive in supporting their study. The second result was Neutral response $(41.19 \%, 33.44 \%$, and $41.11 \%)$, which were in middle 
number, and the last was strongly disagree and disagree response $(8 \%, 2.63 \%$, and $6.69 \%)$ which were in very small number.

\section{Open-Ended Questionnaire Result}

Next, the writer used the open-ended questionnaire to get deep information and support the data of closed-ended questionnaire. The result of the question will be classified and explained more. Here were the following questions and the number of respondents:

Table 3: Open-Ended Questionnaire

\begin{tabular}{llc}
\hline No. & \multicolumn{1}{c}{ Questions } & Respondents \\
\hline & $\begin{array}{l}\text { Do you think PowerPoint has a } \\
\text { positive impact as a learning media } \\
\text { in learning English? Please give a } \\
\text { reason, either yes or no! }\end{array}$ & 900 \\
\hline
\end{tabular}

Below was given and presented the students' answers towards one open-ended question in details:

\begin{tabular}{|c|c|}
\hline Respondents & Answers \\
\hline Respondent 1 & $\begin{array}{l}\text { In my opinion, it's easier to use a PowerPoint because it's easy to record or } \\
\text { remember }\end{array}$ \\
\hline Respondent 2 & Yes, because it's easier to use \\
\hline Respondent 3 & $\begin{array}{l}\text { It is very positive because, if we use PowerPoint, we can take a picture to } \\
\text { understand. After all, many students underestimate the subject. }\end{array}$ \\
\hline Respondent 4 & $\begin{array}{l}\text { Yes, because the material presented is more interesting and easier to } \\
\text { understand }\end{array}$ \\
\hline Respondent 5 & Yes, because I feel more interested in learning. \\
\hline Respondent 6 & Yes, because power points make it easier \\
\hline Respondent 7 & $\begin{array}{l}\text { Yeah... Because PowerPoint applications that can be used on mobile phones } \\
\text { too }\end{array}$ \\
\hline Respondent 8 & Yes, because it becomes more understanding and makes students concentrate \\
\hline Respondent 9 & Yes, because it's easy to understand \\
\hline $\begin{array}{l}\text { Respondent } \\
10\end{array}$ & $\begin{array}{l}\text { Yes because in my opinion the current generation of children prefers something } \\
\text { that is not monotonous like a book that only has writing and pictures, whereas in } \\
\text { PowerPoint it can be equipped with animation or video and audio that can make } \\
\text { students easier to remember and eager to follow the lesson, so that it automatically } \\
\text { the value of student learning can increase }\end{array}$ \\
\hline
\end{tabular}




\begin{tabular}{ll}
$\begin{array}{l}\text { Respondent } \\
\mathbf{1 1}\end{array}$ & $\begin{array}{l}\text { Yes, because in order to better understand basic English words / sentences and } \\
\text { be more interesting and easier to understand }\end{array}$ \\
\hline $\begin{array}{l}\text { Respondent } \\
\mathbf{1 2}\end{array}$ & $\begin{array}{l}\text { Agree, in my opinion by using Powerpoint, I can better understand the material } \\
\text { provided by the teacher, especially in English lessons. The teacher no longer } \\
\text { needs to write at length on the board, using PowerPoint will make it easier and } \\
\text { more time efficient. }\end{array}$ \\
\hline $\begin{array}{l}\text { Respondent } \\
\mathbf{1 3}\end{array}$ & $\begin{array}{l}\text { Positive, while it can be an alternative media to provide knowledge to other } \\
\text { students }\end{array}$ \\
\hline $\begin{array}{l}\text { Respondent } \\
\mathbf{1 4}\end{array}$ & Yes, in my opinion is positive, because learning is easier to understand \\
\hline
\end{tabular}

Respondent Yes, agree, because with that we focus more on the core of the lesson when 15 compared with the book. In addition, the use of paper will also be reduced because power points rely more on technology
Respondent Yes, because I feel more understanding when my teacher teaches using 16 PowerPoint
Respondent I don't agree with using power points too often because many students don't 17 focus on power points in front of them, and using power points has a lot of concentration of students who are not at the power point. I prefer to combine the learning with PowerPoint and book because more understanding for students, not to be lazy to write, and when using books the interaction between teacher and student is more entered.
Respondent In my opinion it is very positive because we as students can clearly know the 18 vocabulary in each letter without any disadvantages and strengths and it is even more interesting if in learning English, add a video story in English so students are more comfortable with how to pronounce the sentence and not make students bored and sleepy.

\section{Respondent No, because I prefer studying with books \\ 19}

Respondent Agree, but it would be better than using PowerPoint should be interspersed 20 with textbooks so that it becomes stronger understanding in learning English

Respondent Yes, learning using PowerPoint media has positive values in learning, because 21 we can be more focused and more interested (because there are animations, colors, images or videos that can be viewed using PowerPoint). And because the teachers use PowerPoint, students can also use it and this media can improve their children's creations (because we are free to edit, provide animation, drawings, transitions) and we can increase knowledge about how to use a laptop (when the teacher gives assignments make PowerPoint).

Respondent In my opinion learning to use a power point is better than using a book because 
Respondent No, because I lack understanding of subject matter through power points.

23

Respondent Yes, because I enjoy listening to learning more after explaining using the power 24 point after that the teacher explains, so we don't get bored listening to the teacher explain it, we can also look at the screen about the shows the teacher gives.

Respondent Disagree because PowerPoint media can be understood by those who pay

25 attention seriously, and those who are not serious can produce negative activities

Respondent Learning to use PowerPoint is very positive because it can make students more

26 concentrated and also we can see any kinds of things that are explained in more detail and do not bore all students

Respondent Yes, because in my opinion learning with power points is also good, but I prefer $27 \quad$ learning with books.

Respondent Agree because it's easier to understand

28

Respondent Agree, because it can increase a student's learning interest

29

Respondent No, When using a power point, it is likely that students interact directly with other 30 students less often in English.

Respondent Yes, because learning with power points is easier to understand because

31 sometimes the teacher gives material through video and animation so that it's easy to understand

Respondent Agree, because learning to use PowerPoint doesn't quickly make you sleepy and $32 \quad$ easier to understand

Respondent No, PowerPoint is easier to use in lessons other than English

33

Respondent No, In my opinion, foreign language learning is less effective if the teacher 34 applies learning through power points, because if the teacher gives an assignment, many students do not understand how to learn with the media and in my opinion the media will be better if the teacher gives direction to the use of power points .

Respondent Yes, using PowerPoint is more interesting

35

Respondent Yes, because in power points we can easily understand in outline or content or 36 important parts of a lesson that are already listed in the power point.

Respondent In my opinion, foreign language learning is less effective if the teacher applies 37 learning through power points, because if the teacher gives an assignment, many students do not understand how to learn with the media and in my opinion the media will be better if the teacher gives direction to the use of power points 


\begin{tabular}{|c|c|}
\hline $\begin{array}{l}\text { Respondent } \\
38\end{array}$ & $\begin{array}{l}\text { Agree, because I understand more by using PowerPoint than others. Explanation } \\
\text { at PowerPoint can be better understood. }\end{array}$ \\
\hline $\begin{array}{l}\text { Respondent } \\
39\end{array}$ & $\begin{array}{l}\text { Yes, PowerPoint is a positive media, because with PowerPoint we become more } \\
\text { understanding and comprehension and easier }\end{array}$ \\
\hline $\begin{array}{l}\text { Respondent } \\
40\end{array}$ & $\begin{array}{l}\text { Agree, because learning to use powerpoint doesn't quickly make you sleepy and } \\
\text { easier to understand. }\end{array}$ \\
\hline $\begin{array}{l}\text { Respondent } \\
41\end{array}$ & I agree because it can add to my value and learning may be easier to understand \\
\hline $\begin{array}{l}\text { Respondent } \\
42\end{array}$ & $\begin{array}{l}\text { No, Because I sat in the back. So, it doesn't seem, especially when told to take } \\
\text { notes my eyes don't look }\end{array}$ \\
\hline $\begin{array}{l}\text { Respondent } \\
43\end{array}$ & Yes, but if English is explained it must be clearer and easier to understand \\
\hline $\begin{array}{l}\text { Respondent } \\
44\end{array}$ & Yes, because with power point we can see visually / images \\
\hline $\begin{array}{l}\text { Respondent } \\
45\end{array}$ & $\begin{array}{l}\text { Yes, because it makes me more enthusiastic and makes me better understand what } \\
\text { is taught by the teacher }\end{array}$ \\
\hline $\begin{array}{l}\text { Respondent } \\
46\end{array}$ & $\begin{array}{l}\text { Power point as a learning media, I think it is a positive thing, because students } \\
\text { can better analyze the material presented, students can see the material presented } \\
\text { more clearly, and have a real picture of the material presented. But the book } \\
\text { remains the core of the material. }\end{array}$ \\
\hline
\end{tabular}
Respondent Agree, in my opinion by using PowerPoint, I am better able to capture / $47 \quad$ understand the material provided by the teacher, especially in English lessons. The teacher no longer needs to write at length on the board, using PowerPoint will make it easier and more time efficient.

\begin{tabular}{ll}
$\begin{array}{l}\text { Respondent } \\
\text { Respondent } \\
\mathbf{4 9}\end{array}$ & Yes, because it adds to the spirit of learning \\
\hline $\begin{array}{l}\text { Respondent } \\
\mathbf{5 0}\end{array}$ & $\begin{array}{l}\text { No, because in English I cannot understand what my teacher is explaining. } \\
\text { Because learning to use power points is also my teacher explaining it faster than } \\
\text { with a book. }\end{array}$ \\
\hline $\begin{array}{l}\text { Respondents } \\
\text { (see more at link below) } \\
\text { https://docs.google.com/spreadsheets/d/In5nttP2dxuaVd5Nq_WR3NObWezLay- } \\
\end{array}$ & ogEQUvK_ccJo8/edit? usp=sharing
\end{tabular}

Based on the students' responses of the open-ended question above, the writer can classify specific reasons from the respondents in choosing the Ms. PowerPoint media used in the classroom. It can be seen that most students answer yes or agree with the Ms. PowerPoint 
that gave positive feeling in learning English. Although, some of them also added additional information that they still had to use whiteboard and notebooks in learning English for the achievement of more effective learning. Below were the details:

\section{a. Positive Perceptions of the Ms PowerPoint}

From the positive responses of the students, the writer found the main reason why most of them $(56,7 \%)$ or 510 respondents said it was good to study using Ms. PowerPoint as learning media was first, it was mostly because of the media technology that can support of the students for learning. Such understanding clear vocabulary in each letter without any advantages and disadvantages, and this response was reported by respondent 18. Also, respondent 21 alleged that the perception of PowerPoint makes students more interested and focused in learning, and more knowledgeable in learning to use media such as enhancing their students' creations in free editing of powerpoints and can mark the extent to which they understand as in the watermark and provide animation, images, transitions. Furthermore, respondent 15 stated the use of paper would also be reduced because power points rely more on technology, as they articulated:

In my opinion, it is very positive because we as students can clearly know the
vocabulary in each letter without any disadvantages and strengths and it is even more
interesting if in learning English, add a video story in English, so students are more
comfortable with how to pronounce the sentence and not make students bored and
sleepy. - Respondent $\mathbf{1 8}$ (open-ended questionnaire, April 5, 2020)

Yes, learning using PowerPoint media has positive values in learning because we can be more focused and more interested (because there are animations, colors, images or videos that can be viewed using PowerPoint). And because the teachers use PowerPoint, students can also use it, and this media can improve their children's creations (because we are free to edit, provide animation, drawings, transitions) and we can increase knowledge about how to use a laptop (when the teacher gives assignments make PowerPoint). - Respondent 21 (open-ended questionnaire, April 5, 2020)

Yes, agree, because with that we focus more on the essence of the lesson when compared with the book. In addition, the use of paper will also be reduced because power points rely more on technology. - Respondent 15 (open-ended questionnaire, April 5, 2020)

In brief, the perception of students in choosing PowerPoint as a learning tool in EFL classroom was mostly positive. Several students reported it.

\section{b. Neutral Perceptions of the PowerPoint}

Based on the results of respondents' data, the students on average neutral answered is $(34,2 \%)$ or 308 respondents and the results were not much different from being positive by only a few percent difference. The authors analyze and focus this section on open-ended which want to deepen their reasons related to their perceptions using powerpoints in learning.

"I don't agree with using power points too often because many students don't focus on power points in front of them, and using power points has a lot of concentration of 
students who are not at the PowerPoint. I prefer to combine the learning with PowerPoint and book because more understanding for students, not to be lazy to write, and when using books, the interaction between teacher and student is more entered." Respondent 17 (open-ended questionnaire, April 5, 2020)

"In my opinion learning to use a PowerPoint is better than using a book because using a PowerPoint is easy to understand and not bored, whereas in a book it's easy to understand but gets tired quickly reading it" - Respondent 22 (open-ended questionnaire, April 5, 2020)

"Powerpoint as a learning media, I think it is a positive thing because students can better analyze the material presented, students can see the material presented more clearly, and have a real picture of the material presented. But the book remains the core of the material." - Respondent 46 (open-ended questionnaire, April 5, 2020)

In short, some students said they were neutral because although PowerPoint is very helpful in learning, books are the key to all of their material, they think that books are also very important in improving their learning if learning outcomes using PowerPoint students feel confused as they are not structured with teaching material them, so students still feel that both are very helpful to them in increasing their knowledge.

\section{c. Negative Perceptions of the PowerPoint}

Referring to the students' negative responses in learning English using Ms. PowerPoints, there were $(9.1 \%)$ or 82 respondents who answered negatively. The writer found some reasons for the responses. They assume that using power points, and there was little possibility of students interacting directly with other students based on Respondent 40. Additionally, Respondent 18 claims that if using PowerPoint media in class only makes students understand who are focused and seriously studying, then others can produce negative activities. Also, Respondent 37 alleged that PowerPoint is less effective for foreign language learning, as they inosculate:

Disagree, When learning to use media as PowerPoint, it is less conversation on students interacts directly with other students using English. - Respondent 40 (open-ended questionnaire, April 5, 2020)

Disagree because PowerPoint media can be understood by those who pay attention seriously, and those who are not serious can produce negative activities. - Respondent 18 (open-ended questionnaire, April 5, 2020)

In my opinion, foreign language learning is less effective if the teacher applies to learn through power points, because if the teacher gives an assignment, many students do not understand how to learn with the media and in my opinion, the media will be better if the teacher gives direction to the use of power points - Respondent 37 (open-ended questionnaire, April 5, 2020)

Shortly, the perception of participants in choosing Ms. PowerPoint as a learning media in EFL classroom got some disapproval from a few students (Respondent 40, 18, \& 37). They reported it that they still had poor knowledge about the use of technology or 
media in learning or any particular reason. Therefore, some students say no with the use of media as a tool in learning English in class.

\section{DISCUSSION}

After the findings have been presented previously, in this segment the writer interpreted and discussed the result of data. As mentioned before, the EFL students' in Jakarta perceived positively to use Ms. PowerPoint as learning media in the context of activeness, motivation, and English competence proven by a high number of percentages in the close-ended questionnaire result. Moreover, the open-ended questionnaire revealed that the use of Ms. PowerPoint media in the classroom provides more motivation, creativity, and activity for students in learning.

From the close-ended questionnaire results, the writer found most of the students thought Ms. PowerPoint was good in activeness context $(50,81 \%)$. The writer assumed the use Ms. PowerPoint was common for higher education students, such as for presentation and discussion either in individual or group tasks in front of the class, and their teachers were also believed to use always Ms. PowerPoint in teaching English in class. Therefore, students become more active in asking, discussing in groups. Halimah (2015) who claimed the benefits of using PowerPoint media in learning, one of them is activating student responses or learning activities, encouraging interactive learning, and providing modified learning resources. Hamalik (2010) added that all activities carried out in the process of interaction using Ms. PowerPoint (teacher and student) can achieve learning goals. The intended activity using Ms. PowerPoint here can emphasize the student's activeness in the learning process as it can create active learning situations.

In similar with students' responses towards the activeness benefit, their responses towards the attractiveness aspect or motivation were also good (66,37\%). The writer found Ms. Powerpoint really motivated them to learn. It can be seen in their answer in the close-ended questionnaire on the findings. The writer assumed Ms. PowerPoint has a high impact on students in giving the motivation to learn in class or outside the classroom, for example, students can improve creatively and can learn more independently using Ms. PowerPoint that can be used on each student's cellphone. This argument was supported by (Amine, Benachaiba, \& Guemide, 2012) who stated that Ms. PowerPoint can facilitate students as devices in the classroom, which will enhance students' strives to increase student motivation in learning English. Ms. PowerPoint' slide showed learners to feel joy, focused, concentrated, and motivated to study the lessons due to the material or not boring (Hafis, 2013). Ms. PowerPoint has impressive effects on students' achievement and motivation. (Abdellatif, 2015).

Again, students' responses towards the use of Ms. PowerPoint that might improve their English competence were good based on student perception of the close-ended questionnaire $(52,19 \%)$. The writer assumed that student might feel their competency in learning English with Ms. PowerPoint was increased because it was helpful for them to study. Based on Iswanto (2007), the results of his research about Ms. PowerPoint showed it could have an effect on the activity of students to follow the teaching and learning process. It also affects students' understanding of the 
material. Moreover, the research from Sriwahyuni and Anhar (2019) figured out that students' cognitive competence can be improved by using PowerPoint sheets in the learning process, and it became a tool for students to develop their critical thinking skills. So, the student can write summaries of learning materials and understand them easily. From the present results, it revealed that students' perceptions were excellent context of English learning competency. Much can be improved not only with their knowledge of English but also can increase their creativity and knowledge about the media being used. Thus, the use of Ms. PowerPoint in the classroom was considered as significant to EFL learners in Jakarta.

However, it cannot be neglected that the neutral results on students' opinions $(41.19 \%$, $33.44 \%$, and $41.11 \%$ ) were almost close to positive. The writer argued that some students who neutral answered might cause from their view of Ms. PowerPoint that is common media, and it should be used and better be combined with other instructional media. Syaha, Luthiawati, and Harsono (2020) stated that the use of PowerPoint is too commonly used in the learning process. Additionally, supported by the results of the open-ended answers in which $(56.7 \%)$ respondents said yes or agreed with positive learning using powerpoints, (34.2\%) respondents said neutral they prefer learning with both books and powerpoints and $(9.1 \%)$ respondents said no or disagreed with the use of powerpoints in learning.

\section{CONCLUSIONS}

This research has successfully found that EFL students' perception of Ms. PowerPoint was positive in three main aspects; activeness, motivation, and English competence. The findings clearly showed that students have a good perception if learning English using Ms. PPT can increase students' activeness, can increase students' motivation, and also can increase students' English competence.

Thus, students felt learning English by using Ms. PowerPoint provided more help than those who said neutral or did not. This data is supported by the results of the open-ended questioner data that the results showed more on the positive side or $(56,7 \%)$ good opinions on the use of Ms. PowerPoint while those who said neutral $(34,2 \%)$, and $(9,1 \%)$ negative answered. Therefore, it can be concluded that students' perceptions of Ms. PowerPoint were good and exciting.

To sum up, students' interaction with Ms. PowerPoint were high, so that they felt more active, creative, and motivated to learn English, and gave effect to their English learning competence. The limitation of this research that the researcher not focusing to deepen this research in the form of experiments and to make specifics in terms. For the future researchers can use the new experiment to gain deepen this research of PowerPoint to improve reading, writing or speaking levels. 


\section{REFERENCES}

Abdellatif, Z. (2015). Exploring students 'perceptions of using powerpoint in enhancing their active participation in the efl classroom action research study. Journal of Literature, Languages and Linguistics, 5, 36-39.

Amine, B. M., Benachaiba, C., \& Guemide, B. (2012). Using multimedia to motivate students in efl classrooms: a case study of english master's students at jijel University, Algeria Bouzar. Malaysian Journal of Distance Education, 14(2), 63-81.

Apperson, J. M., Laws, E. L., \& Scepansky, J. A. (2006). The impact of presentation graphics on students' experience in the classroom. Elsevier Computer \& Education, 47, 116-126.

Frandsen, T. L. (2011). Microsoft office powerpoint. London: Bookboon.

Creswell, J. W., \& Plano Clark, V. L. (2011). Choosing a mixed methods design. Designing and conducting mixed methods research, 2, 53-106.

Gusnita, O. (2016). Students' perception toward the use of Power point in teaching learning process at sman 6 Solok Selatan [Doctoral dissertation, STKIP PGRI Sumatera Barat].

Hafis, M. (2013). Students' perception of the use of powerpoint slide show for teaching english subject. Jurnal Pendidikan Bahasa, 2(2), 203-218.

Iswanto, H. (2007). Pemanfaatan multimedia power point untuk meningkatkan motivasi dan hasil belajar siswa di smp Roudlotus Saidiyyah Semarang [Doctoral dissertation, Universitas Negeri Semarang].

Munaroh, M. (2017). Pengaruh penggunaan media power point terhadap aktivitas belajar siswa kelas x sma Islam Bawari Pontianak [Doctoral dissertation, Tanjungpura University].

Rahmi, R. (2014). The used of multimedia in english language teaching. Getsempena English Education Journal, 1(2), 64-79.

Sriwahyuni, W., \& Anhar, A. (2019). The effect of sheet powerpoint in mind map and entry behavior towards students ' cognitive competence in learning natural science in grade VIII of smpn 5 Bukittinggi. International Journal of Progressive Sciences and Technologies, 13(1), $46-53$.

Syaha, M. F. J., \& Harsono, E. R. L. (2020). The development of motion-graphic media in learning: an advanced use of powerpoint in schools X and Y generation teachers. Development, 12(2). 